\title{
EFEK INHIBISI ENZIM $\alpha$-GLUKOSIDASE DARI EKSTRAK ETIL ASETAT, ETANOL, DAN INFUSA DAUN JAMBU MENTE (Anacardium occidentale Linn)
}

\author{
Musyirna Rahmah Nasution, Maria Yella Ladiona, Enda Mora \\ Sekolah Tinggi Ilmu Farmasi Riau, Pekanbaru, Riau \\ Email: musyirnarahmah@yahoo.com
}

\begin{abstract}
ABSTRAK
Telah dilakukan penelitian uji efek inhibisi enzim $\alpha$-glukosidase dari ekstrak etil asetat, etanol, dan infusa daun jambu mente (Anacardium occidentale Linn). Penelitian ini menggunakan metoda spektrofotometri dengan substrat $p$-nitrofenil- $\alpha$-D-glukopiranosida. Hasil pengujian menunjukkan bahwa nilai IC $_{50}$ ekstrak etil asetat terhadap inhibisi enzim $\alpha$-glukosidase sebesar $700,696 \mu \mathrm{g} / \mathrm{ml}$. Sedangkan nilai $\mathrm{IC}_{50}$ ekstrak etanol sebesar $259,840 \mu \mathrm{g} / \mathrm{ml}$. Akarbose sebagai pembanding memiliki nilai $\mathrm{IC}_{50}$ sebesar $0,128 \mu \mathrm{g} / \mathrm{ml}$. Selain pengujian ekstrak, dilakukan juga pengujian infusa berdasarkan penggunaan masyarakat secara tradisional yang memberikan daya inhibisi enzim $\alpha$-glukosidase pada konsentrasi $0,5 \mathrm{~g} / \mathrm{ml}$ sebesar 98,006 \%.
\end{abstract}

Kata Kunci: $\alpha$-glukosidase, inhibisi, daun jambu mente

\section{PENDAHULUAN}

Diabetes mellitus adalah keadaan hiperglikemia disertai berbagai kelainan akibat gangguan hormonal. Pengobatan diabetes mellitus pada prinsipnya adalah menjaga agar kadar glukosa darah dapat dipertahankan pada kondisi normal (80-120 $\mathrm{mg} / \mathrm{dl}$ ). Diabetes mellitus juga dapat dikontrol dengan melakukan upaya seperti perencanaan diet, mempertahankan bobot badan normal, dan melakukan olahraga yang cukup. Obat hanya perlu diberikan apabila setelah melakukan berbagai upaya tersebut secara maksimal tidak berhasil mengendalikan kadar glukosa darah (Ganiswara, 1999).

Inhibitor $\alpha$-glukosidase digunakan untuk mengobati diabetes mellitus tipe II. Kerja antihiperglikemik dari inhibitor $\alpha$ glukosidase merupakan inhibisi kompetitif terhadap enzim-enzim pencernaan di usus halus. Enzim-enzim ini berperan pada hidrolisis karbohidrat makanan menjadi glukosa dan monosakarida lainnya. Pada penderita diabetes mellitus, inhibisi terhadap enzim ini menyebabkan penghambatan absorpsi glukosa sehingga menurunkan keadaan hiperglikemia setelah makan.

Kebanyakan obat antidiabetes oral memberikan efek samping yang tidak diinginkan sehingga para ahli mengembangkan sistem pengobatan tradisional untuk diabetes mellitus yang relatif aman (Agoes, 1991). Tanaman merupakan sumber yang kaya akan inhibitor $\alpha$-glukosidase serta memiliki penghambatan aktivitas $\alpha$-glukosidase yang kuat, sehingga dapat digunakan untuk terapi hiperglikemia yang efektif (Nguyen et al, 2010). Hal tersebut menyebabkan banyak dilakukan penelitian untuk mencari inhibitor $\alpha$ glukosidase yang berasal dari tanaman untuk mengobati diabetes mellitus (Gao et al, 2008).

Salah satu tanaman yang dimanfaatkan khasiatnya adalah daun jambu mente (Anacardium occidentale Linn). Tanaman ini secara empiris digunakan sebagai 
antidiabetes, tetapi belum diteliti aktivitasnya sebagai inhibitor $\alpha$-glukosidase. Kandungan senyawa kimia yang terdapat dalam daun jambu mente menunjukkan adanya golongan flavonoid, tanin, kuinon, dan saponin (Syaharuddin $d k k, 2007$ ).

Adapun penelitian yang telah dilakukan pada daun jambu mente (Anacardium occidentale Linn) seperti efek hipoglikemik dari ekstrak metanol daun jambu mente pada tikus yang diinduksi streptozotosin (Sokeng et al, 2007; Ukwenya et al, 2012).

Berdasarkan hal tersebut, dilakukan penelitian antidiabetes yang bertujuan untuk mengetahui aktivitas inhibisi enzim $\alpha$ glukosidase dari ekstrak etil asetat dan etanol daun jambu mente (Anacardium occidentale Linn).

\section{METODOLOGI PENELITIAN}

\section{Alat dan Bahan}

Alat-alat yang digunakan: alat destilasi, rotary evaporator, $\mathrm{pH}$ meter, microplate reader 96 wells, inkubator, timbangan analitik (Acculab), sentrifuse, vortex mixer (VM-2000), pipet mikro 10-100 $\mu \mathrm{l}$ dan 100$1000 \mu 1$ (Eppendorf), eppendrorf tube dan peralatan gelas yang biasa digunakan di laboratorium.

Bahan yang digunakan adalah aquadest, metanol, etil asetat, $n$-heksan, larutan buffer fosfat $\mathrm{pH} 7$ (Sigma-aldrich, USA), Bovin serum albumin (BSA) (Merck, jerman), enzim $\alpha$-glukosidase (Sigma-aldrich, USA), substrat p-nitrofenil- $\alpha$-D-glukopiranosa (Sigma-aldrich, USA), acarbose (Glucobay ${ }^{\circledR}$ ), dimetilsulfoksida (Sigmaaldrich, USA), larutan $\mathrm{Na}_{2} \mathrm{CO}_{3}$ (Sigmaaldrich, USA).

\section{Pengambilan dan Identifikasi Sampel}

Sampel dari bagian daun tanaman jambu mente yang akan diteliti diambil di Jalan Tanjung Jaya Kecamatan Bukit Raya, Pekanbaru. Identifikasi tanaman dilakukan di Laboratorium Botani oleh tim botani jurusan biologi Fakultas Matematika dan Ilmu Pengetahuan Alam Universitas Riau.

\section{Pembuatan Ekstrak, Fraksinasi sampel dan Uji Fitokimia}

Daun jambu mente segar dikumpulkan dan dicuci bersih, kemudian dikering anginkan, dirajang dan ditimbang. Lalu dimaserasi dengan menggunakan pelarut etanol hingga terendam dengan sempurna. Wadah ditutup rapat dan campuran disimpan di tempat yang terlindung dari cahaya selama 3-5 hari sambil diaduk berulang. Selanjutnya filtrat diambil melalui penyaringan dan ditambah kembali dengan pengekstrak ke dalam wadah sampel, maserasi dilakukan sebanyak tiga kali. Maserat yang didapat kemudian dikentalkan dengan rotary evaporator sampai didapat ekstrak kental. Kemudian ekstrak kental etanol tersebut di fraksinasi menggunakan pelarut $n$-heksan dan residunya difraksi dengan etil asetat. Hasil dari fraksinasi dipekatkan dengan rotary evaporator sehingga diperoleh ekstrak kental fraksi $n$ heksan dan etil asetat. Hasil dari masingmasing ekstrak ditimbang dan dilakukan uji fitokimia diantaraya uji senyawa saponin, fenolik, flavonoid, terpenoid, steroid dan alkaloid.

Uji inhibisi enzim a-glukosidase secara in vitro

Pada microplate 96 wells dicampurkan $10 \mu \mathrm{l}$ sampel (ekstrak/infusa), $50 \mu \mathrm{l}$ buffer fosfat ( $\mathrm{pH} 7$ ), $25 \mu \mathrm{l}$ substrat p-nitrofenil- $\alpha$ D-glukopiranosida, dan $25 \mu \mathrm{l}$ enzim $\alpha$ glukosidase. Lalu campuran diinkubasi selama 30 menit pada suhu $37^{\circ} \mathrm{C}$. Setelah 30 menit, reaksi dihentikan dengan penambahan $100 \mu \mathrm{l}$ larutan $\mathrm{Na}_{2} \mathrm{CO}_{3}$. Kemudian absorban dari $p$-nitrofenol yang terbentuk diukur dengan spektrofotometer UV-vis pada panjang gelombang $410 \mathrm{~nm}$. Pengujian yang sama dilakukan pada 
konsentrasi 500, 250, 125, dan $62 \mu \mathrm{g} / \mathrm{ml}$. Dapat dilihat pada tabel 1. Sebagai kontrol positif digunakan tablet Glucobay yang mengandung zat aktif akarbose (Sancheti et $a l, 2009)$.

Tabel 1.

Kondisi reaksi uji inhibisi $\alpha$-glukosidase

\begin{tabular}{ccccccc}
\hline \multirow{2}{*}{ Reagen } & \multicolumn{7}{c}{ Volume $(\mu \mathrm{l})$} \\
\cline { 2 - 7 } & Bo & B1 & So & S1 & Ao & A1 \\
\hline Sampel & - & - & 10 & 10 & 10 & 10 \\
DMSO & 10 & 10 & - & - & - & - \\
Bufer & 50 & 50 & 50 & 50 & 50 & 50 \\
fosfat & 25 & 25 & 25 & 25 & 25 & 25 \\
PNPG & - & 25 & - & 25 & - & 25 \\
Enzim & \multicolumn{7}{c}{$37^{\circ} \mathrm{C}, 30$ menit } & & \\
Inkubasi & 100 & 100 & 100 & 100 & 100 & 100 \\
$\mathrm{Na}_{2} \mathrm{CO}_{3}$ & 100
\end{tabular}

Keterangan: $\mathrm{Bo}=$ kontrol blanko, $\mathrm{B} 1=$ blanko, $\mathrm{So}=$ kontrol sampel, $\mathrm{S} 1=$ sampel, $\mathrm{Ao}=$ kontrol akarbose, $\mathrm{A} 1=$ akarbose

Persen inhibisi(\% I) dihitung dengan rumus:

$$
\% \mathrm{I}=\frac{\mathrm{A}_{\text {kontrol }}-\mathrm{A}_{\text {sampel }} \mathrm{X} 100 \%}{\mathrm{~A}_{\text {kontrol }}}
$$

\section{HASIL DAN PEMBAHASAN}

Pengujian fitokimia yang bertujuan untuk mengetahui keberadaan metabolit sekunder yang diharapkan dapat berfungsi sebagai antidiabetes. Pengujian fitokimia meliputi pengujian alkaloid, steroid, flavonoid, saponin, fenolik, dan terpenoid. Hasil pengujian fitokimia daun jambu mente menunjukkan bahwa pada ekstrak etil asetat mengandung senyawa flavonoid dan fenolik. Sedangkan pada ekstrak etanol dan infusa mengandung senyawa flavonoid, fenolik, dan saponin.

Menurut penelitian Kumar et al (2011), senyawa metabolit sekunder yang dapat menghambat aktivitas enzim $\alpha$-glukosidase antara lain flavonoid, alkaloid, fenolik, dan terpenoid. Beberapa senyawa flavonoid yang dapat menghambat aktivitas enzim $\alpha$ glukosidase seperti isoflavon dan flavonol.
Komponen flavonoid pada tanaman berikatan dengan gula sebagai glikosida. Flavonoid sangat efektif digunakan sebagai antioksidan, antibakteri, dan inhibitor enzim $\alpha$-glukosidase. Hal ini terbukti dari hasil penelitian ekstrak flavonoid buah mahkota dewa dengan konsentrasi $1 \%(\mathrm{~b} / \mathrm{v})$ mampu menginhibisi aktivitas enzim $\alpha$-glukosidase sebesar 23,06-40,26 \% (Hartika, 2009).

Uji penghambatan aktivitas $\alpha$ glukosidase merupakan uji terhadap senyawa yang berpotensi sebagai antidiabetes karena penghambatan enzim $\alpha$ glukosidase mampu menurunkan kadar glukosa darah. Biasanya obat antidiabetes mengandung senyawa-senyawa yang bisa menghambat kerja enzim $\alpha$-glukosidase yang berperan dalam pemecahan karbohidrat menjadi gula darah (Hanefeld, 2007).

Penghambatan enzim $\alpha$-glukosidase menghambat secara kompetitif. Hal ini terjadi ketika inhibitor dan substrat berikatan dengan enzim pada sisi aktif yang sama karena substrat dan inhibitor memiliki struktur yang sama. Penghambatan kompetitif tidak mengubah kecepatan reaksi maksimum karena ikatan inhibitor reversible dapat diatasi dengan konsentrasi substrat yang tinggi, tetapi ikatan substrat-enzim lemah dan afinitas ikatannya terlihat menurun.

Pengujian inhibisi enzim $\alpha$-glukosidase dilakukan dengan reaksi enzimatis secara in vitro menggunakan spektrofotometer UVvis pada panjang gelombang $410 \mathrm{~nm}$. Pada uji ini, enzim $\alpha$-glukosidase akan menghidrolisis substrat p-nitrofenil- $\alpha-\mathrm{D}$ glukopiranosida menjadi $p$-nitrofenol yang berwarna kuning dan glukosa. Aktivitas enzim diukur berdasarkan hasil absorbansi $p$-nitrofenol yang berwarna kuning (Artanti $d k k$, 2002). Apabila memiliki kemampuan menghambat aktivitas enzim $\alpha$-glukosidase, 
maka $p$-nitrofenol yang dihasilkan akan berkurang (Sugiwati, 2005).

Pengujian sampel menggunakan ekstrak etil asetat, etanol, dan infusa. Ekstrak dilarutkan dengan dimetilsulfoksida untuk membantu melarutkan ekstrak. Larutan sampel dibuat sebanyak lima konsentrasi, yaitu 1000, 500, 250, 125, dan $62 \mu \mathrm{g} / \mathrm{ml}$ untuk melihat perubahan aktivitas penghambatan terhadap enzim $\alpha$ glukosidase, sedangkan infusa tidak dibuat serial konsentrasinya dan pengujian dilakukan sebanyak 3 pengulangan. Buffer fosfat digunakan untuk menjaga $\mathrm{pH}$ dari larutan enzim dan substrat tetap pada $\mathrm{pH} 7$, sedangkan larutan natrium karbonat digunakan sebagai larutan penghenti reaksi enzim. Natrium karbonat dipilih sebagai penghenti reaksi sebab mampu meningkatkan $\mathrm{pH}$ larutan uji menjadi basa, sehingga enzim akan terdenaturasi. Analisa inhibisi enzim $\alpha$-glukosidase ini menggunakan microplate 96 wells. Larutan uji dibuat sebagai kontrol blanko, blanko, kontrol sampel, dan sampel (Kurnia, 2011).

Tujuan dibuat kontrol blanko adalah untuk mengetahui bila bahan-bahan yang digunakan dalam larutan uji memberikan serapan pada panjang gelombang $410 \mathrm{~nm}$ dan untuk mengetahui kemungkinan enzim $\alpha$-glukosidase pada blanko masih aktif atau tidak setelah penambahan larutan penghenti natrium karbonat. Pada pengujian larutan sampel, nilai serapan bisa saja tidak murni berasal dari $p$-nitrofenol yang terbentuk tetapi dapat juga dipengaruhi oleh serapan sampel yang berwarna yang dapat memberikan nilai serapan pada panjang gelombang pengukuran yang digunakan. Maka, pengujian kontrol sampel diperlukan untuk menghilangkan nilai serapan dari ekstrak yang berwarna tanpa adanya aktivitas enzim karena telah dibasakan oleh natrium karbonat.
Pengujian aktivitas inhibisi enzim $\alpha$ glukosidase terhadap beberapa serial konsentrasi sampel menunjukkan bahwa inhibisi enzim $\alpha$-glukosidase dari ekstrak etil asetat pada konsentrasi $1000 \mu \mathrm{g} / \mathrm{ml}$ sebesar $71,970 \%$ dan ekstrak etanol sebesar 88,117 $\%$ (Gambar 1). Dari hasil penelitian tersebut dapat diketahui bahwa ekstrak etanol memiliki aktivitas penghambatan enzim $\alpha$ glukosidase yang lebih besar dibandingkan dengan ekstrak etil asetat. Hal ini dapat terlihat dari perbedaan jumlah kandungan senyawa metabolit sekunder yang terdapat pada ekstrak etil asetat dan ekstrak etanol dimana ekstrak etil asetat hanya mengandung senyawa flavonoid dan fenolik, sedangkan ekstrak etanol mengandung senyawa flavonoid, fenolik, dan saponin.

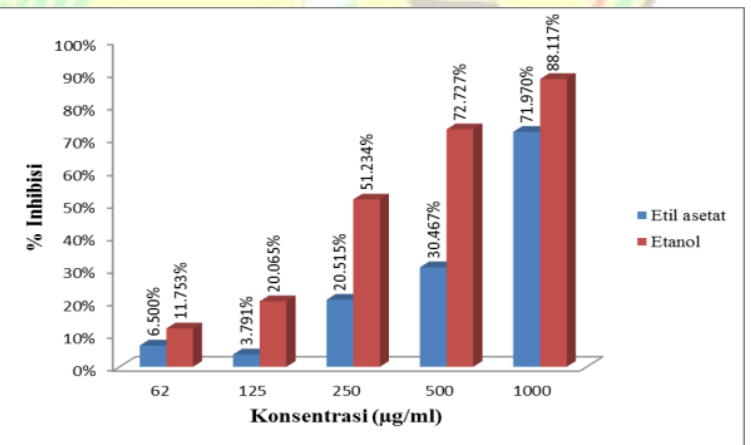

Gambar 1.

Diagram batang persen inhibisi enzim $\alpha$ glukosidase dari ekstrak etil asetat dan etanol

Sebagai pembanding digunakan senyawa inhibitor akarbose. Akarbose digunakan sebagai standar karena akarbose telah digunakan secara luas sebagai obat di Indonesia serta lebih mudah didapat dan banyak digunakan sebagai pembanding pada berbagai literatur (Shinde et al, 2008). Akarbose dikenal dengan nama Glucobay. Obat ini digunakan untuk menghambat kerja enzim yang memecah karbohidrat menjadi glukosa. Akarbose secara kompetitif menghambat hidrolisis enzimatik oligosakarida oleh enzim $\alpha$-glukosidase di 
usus halus. Pada pengujian daun jambu mente didapatkan persen inhibisi akarbose sebesar 92,927 \% dimana pengujian ini menggunakan tablet Glucobay.

Nilai $\mathrm{IC}_{50}$ merupakan bilangan yang menunjukkan konsentrasi ekstrak $(\mu \mathrm{g} / \mathrm{ml})$ yang mampu menghambat $50 \%$ aktivitas enzim $\alpha$-glukosidase. Nilai $\mathrm{IC}_{50}$ ekstrak dibandingkan dengan nilai $\mathrm{IC}_{50}$ pembanding (akarbose). Nilai $\mathrm{IC}_{50}$ yang kecil disebabkan oleh persen inhibisi yang besar dari variasi konsentrasi ekstrak, sedangkan besarnya nilai persen inhibisi disebabkan kandungan zat aktif yang menghambat enzim $\alpha$ glukosidase juga besar. Pada penelitian ini akarbose sebagai pembanding memiliki nilai $\mathrm{IC}_{50}$ sebesar $0,128 \mu \mathrm{g} / \mathrm{ml}$ yang berarti bahwa pada konsentrasi ini akarbose mampu menghambat aktivitas enzim $\alpha$-glukosidase sebesar 50\% (Tabel 2).

Tabel 2.

Data perbandingan nilai $\mathrm{IC}_{50}$ dari ekstrak etil asetat, etanol daun jambu mente dan akarbose

\begin{tabular}{ccc}
\hline No & Sampel & IC $_{\mathbf{5 0}}(\boldsymbol{\mu} \mathbf{g} / \mathbf{m l})$ \\
\hline 1 & Ekstrak etil asetat & 700,696 \\
2 & Ekstrak etanol & 259,840 \\
3 & Akarbose & 0,128 \\
\hline
\end{tabular}

Dari pengujian tersebut dapat diketahui bahwa ekstrak etanol memiliki aktivitas inhibisi enzim $\alpha$-glukosidase yang lebih besar dibandingkan dengan ekstrak etil asetat. Tetapi, kedua ekstrak ini memiliki aktivitas inhibisi enzim $\alpha$-glukosidase yang lebih kecil dibandingkan dengan akarbose.

\section{KESIMPULAN}

Nilai IC50 ekstrak etil asetat terhadap inhibisi enzim $\alpha$-glukosidase sebesar $700,696 \mu \mathrm{g} / \mathrm{ml}$ dan nilai IC50 ekstrak etanol terhadap inhibisi enzim $\alpha$-glukosidase sebesar $259,840 \mu \mathrm{g} / \mathrm{ml}$ dengan pembanding akarbose yang memiliki nilai IC50 sebesar $0,128 \mu \mathrm{g} / \mathrm{ml}$.

\section{DAFTAR PUSTAKA}

Anonim., 2010, Keputusan Mentri Kesehatan RI No. 492/MENKES Per/IV/ 2010 tentang Persyaratan kualitas air minum. Departemen Kesehatan, www.depkes.go.id, diakses 25 Mei 2013.

Agoes, A., 1991, Pengobatan Tradisional di Indonesia, Medika, No. 8, Thn. 17, Hal. 632

Artanti, N., Hanafi, M., dan Kardono, L. B. S., 2002, Aktivitas Penghambatan Ekstrak Gambir (Uncaria gambir Roxb) dan Ekstrak Taxus sumatrana (Miquel) de Laubenfels Terhadap Enzim $\alpha$ glukosidase, Prosiding Temu-Ilmiah Jaringan Kerjasama Kimia Indonesia Seminar Nasional $V$ Kimia Dalam Pembangunan, Hal. 483-488

Ganiswara, S. G., 1999, Farmakologi dan Terapi, Edisi 4, Fakultas Kedokteran Universitas Indonesia, Jakarta

Gao, Hong., Huang, Yi-Na., Gao, Bo., Xu, Pei-Yu., Inagaki, Chika., Kawabata, Jun., 2008, $\alpha$-Glucosidase Inhibitory Effect by the Flower Buds of Tussilago farfara L, Food Chemistry 106, 1195 1210

Hanefel, M., 2007, Cardiovascular Benefit and Safety Profile of Acarbose Therapy in Prediabetes and Established Type 2 Diabetes, Cardiovase diabetol 6: 20

Harborne, J. B., 1987, Metode Fitokimia Penuntun Cara Modern Menganalisis Tumbuhan, Edisi II, ITB, Bandung

Hartika, R., 2009, Aktivitas Inhibisi $\alpha$ glukosidase Ekstrak Senyawa Flavonoid Buah Mahkota Dewa, Skripsi, Departemen Kimia Fakultas Matematika dan Ilmu Pengetahuan Alam, Institut Pertanian Bogor, Bogor

Kumar, S., Narwal, S., Kumar, V., Prakash, O., 2011, $\alpha$-glucosidase Inhibitors From Plants: A Natural Approach to 
Treat Diabetes, Institute of Pharmaceutical Sciences, Kurukshetra University, India

Kurnia, E., 2011, Uji Aktivitas

Penghambatan $\alpha$-glukosidase dan

Penapisan Fitokimia dari Beberapa

Tanaman Famili Apocynaceae dan

Clusiaceae, Skripsi, Fakultas

Matematikan dan Ilmu Pengetahuan

Alam, Jurusan Farmasi, Universitas Indonesia, Depok

Nguyen, X. N., Kiem, P. V., Minh, C. V.,

Ban, N. K., Cuong, N. X., Tung, N. H., Ha, L. M., Ha, D. T., Tai, B. H., Quang,

T. H., 2010, $\alpha$-glucosidase Inhibition Properties of Cucurbitane-type Triterpene Glycosides from the Fruits of Momordica charantia, Chem. Pharm. Bull 58, 720-724

Sancheti, S., Sancheti, S., Sung-Yum, S., 2009, Chaenomeles Sinensis: A potent $\alpha$-and $\quad \beta$-Glucosidase Inhibitor, American Journal of Pharmacology and Toxicology, Department of Biology, Kongju National University, Korea

Shinde, J., Taldone, T., Barletta, M., Kunaparaju, N., Bo, H., Kumar, S., 2008, Alpha-glucosidase Inhibitory Activity of Syzygium cumini (Linn.) Skeels Seed Kernel In Vitro and In Goto-Kakizaki (GK) Rats, Carbohydrate Research 343, 1278-1281
Sokeng, S. D., Lontsi, D., Moundipa, P. F., Jatsa, H. B., 2007, Hypoglycemic Effect of Anacardium occidentale L Methanol Extract and Fractions on Streptozotocin-induced Diabetic Rats, Global Journal of Pharmacology 1 (1): 01-05, Department of Biological Sciences, University of Ngaoundere, Cameroon

Sugiwati, S., 2005, Aktivitas Antihiperglikemik dari Ekstrak Buah Mahkota Dewa (Phaleria macrocarpa (Scheff) Boerl) Sebagai Inhibitor AlfaGlukosidase Invitro dan Invivo Pada Tikus Putih, Tesis, Institut Pertanian Bogor, Bogor

Syaharuddin, Padmawinata, K., dan Soetarno, S., 2007, Isolasi dan Penentuan Struktur Senyawa Kimia dalam Daun Jambu Mete (Anacardium occidentale Linn), Sekolah Farmasi ITB, Bandung

Ukwenya, V. O., Ashaolu, J. O., Adeyemi, A. O., Akinola, O. A., Martins, E. A., 2012, Antihyperglycemic Activities of Methanolic Leaf Extract of Anacardium occidentale Linn on the Pancreas of Streptozotocin-induced Diabetic Rats, Journal of Cell and Animal Biology, Vol.6, Department of Anatomy, Faculty of Basic Medical Sciences Bowen University, Nigeria. 